\title{
Expression of the H-subunit and L-subunit of ferritin in bone marrow macrophages and cells of the erythron during cellular immune activation
}

\author{
A.M. Koorts ${ }^{\text {a,* }}$, P.F. Levay ${ }^{\text {b }}$, A.N. Hall ${ }^{\text {c }}$, C.F. van der Merwe ${ }^{\text {c }}$, P.J. Becker ${ }^{\text {a,d }}$, M. Viljoen ${ }^{\text {a }}$ \\ a Department of Physiology, School of Medicine, Faculty of Health Sciences, University of Pretoria, Pretoria, South Africa \\ b Department of Internal Medicine, Kalafong Hospital, University of Pretoria, Pretoria, South Africa \\ c Laboratory for Microscopy and Microanalysis, University of Pretoria, Pretoria, South Africa \\ d Biostatistics Unit, Medical Research Council, Pretoria, South Africa
}

\section{A R T I C L E I N F O}

\section{Article history:}

Submitted 9 March 2011

Revised 6 April 2011

Available online $\mathrm{xxxx}$

(Communicated by Hal E. Broxmeyer, PhD., 11 April 2011)

\section{Keywords:}

Ferritin

Isoferritins

H-subunit

L-subunit

Iron

Cellular immune activation

\begin{abstract}
A B S T R A C T
Background: The expression of the two types of ferritin subunits, the H-subunit and L-subunit, has been shown to be differentially regulated by cytokines. The primary aim of the present study was to quantitatively measure the expression of the $\mathrm{H}$-subunit and L-subunit of ferritin in bone marrow macrophages and cells of the erythron in patients with chronic T-helper cell type-1 immune stimulation.

Methods: The expression of the H-subunit and L-subunit of ferritin in bone marrow macrophages and cells of the erythron was quantitatively evaluated by post-embedding immunolocalisation with immunogold transmission electron microscopy.

Results: The present study showed up-regulation of the $\mathrm{H}$-subunit of ferritin in the bone marrow macrophage in patients with pronounced cellular immune activation ( $94.7 \pm 37.3$ counts $/ \mu \mathrm{m}^{2} ; \mathrm{n}=31 \mathrm{vs} 72.4 \pm 34.0$ counts/ $\mu \mathrm{m}^{2} ; \mathrm{n}=13$, $\mathrm{p}$-value $=0.037$ ).

Conclusion: This supports a possible role for H-subunit rich ferritins in the hypoferraemia of chronic disease.
\end{abstract}

(c) 2011 Elsevier Inc. All rights reserved.

\section{Introduction}

Ferritin is the intracellular protein responsible for the sequestration, storage and release of iron. Ferritin can accumulate up to 4500 iron atoms as a ferrihydrite mineral in a protein shell and releases these iron atoms when there is an increase in the cell's need for bioavailable iron [1]. The ferritin protein shell consists of 24 protein subunits of two types, the H-subunit and the L-subunit. These ferritin subunits perform different functions in the mineralization process of iron [2]. The ferritin protein shell can exist as various combinations of these two subunit types, giving rise to heteropolymers or isoferritins. Isoferritins are functionally distinct and it would appear that characteristic populations of isoferritins are found depending on the type of cell, the proliferation status of the cell and the presence of disease [3]. Most of the ferritin produced intracellularly is harnessed for the regulation of iron bio-availability. However, some of the ferritin is secreted and internalised by other cells [4]. In addition to the regulation of iron bio-availability, ferritin may contribute to the control of myelopoiesis and immunological responses [5].

\footnotetext{
* Corresponding author at: Department of Physiology, Faculty of Health Sciences, Private Bag x323, Arcadia, 0007, South Africa. Fax: +27 123211679.

E-mail address: akoorts@medic.up.ac.za (A.M. Koorts).
}

Plasma ferritin is increased as an acute phase protein during conditions of infection, inflammation and malignancies. Its expression is also up-regulated in the cytosol of various cells in conditions of uncontrolled cellular proliferation, in any condition marked by excessive production of toxic oxygen radicals, and by infectious and inflammatory processes [6]. Under such conditions ferritin upregulation is predominantly stimulated by reactive oxygen radicals and by cytokines $[7,8]$. The major function of ferritin in these conditions is to reduce the bio-availability of iron in order to stem uncontrolled cellular proliferation and excessive production of reactive oxygen radicals [9]. Ferritin is, however, not indiscriminately up-regulated as a shift towards a predominance in $\mathrm{H}$-subunit rich ferritins would appear to occur [10-18].

The expression of the $\mathrm{H}$-subunit and L-subunit and the relationship between these subunits depend, not only on the type of cell, but also on the role of the cell in iron homeostasis and on various other factors that can influence the expression of the H-subunit and L-subunit of ferritin [19]. Since the role that the macrophage on the one hand, and the cells of the erythron on the other, play in iron homeostasis differs, it is possible that these subunits would be expressed differently.

In this study the expression of the H-subunit and L-subunit of ferritin was determined in the bone marrow macrophage and in cells of the erythron in combination with the inflammatory status of patients with cellular immune activation. 


\section{Materials and methods}

\section{Patients}

The study group consisted of 44 patients attending the Department of Internal Medicine, Kalafong Hospital, South Africa, for treatment of chronic diseases. Blood and bone marrow were collected from each patient. The diagnosis of the patients were diverse and included various types of infections (tuberculosis (TB), malaria, human immunodeficiency virus (HIV)), cancers (lung, breast), pancytopenias as a result of bone marrow suppression or peripheral destruction of blood cells, organ failures including renal failure, heart failure and liver failure, anaemias with different etiologies and various other pathologies. This resulted in an extremely heterogeneous group of patients. For the purpose of this study the immune status based on neopterin and cytokine activity were used to group the patients. Ethical clearance for the study was obtained from the Faculty of Health Sciences Research Ethics Committee, University of Pretoria (ethical clearance number 118/2003), and all patients gave informed consent.

\section{Determination of neopterin}

Neopterin measurements were performed by a neopterin ELISA (DRG Diagnostics, Germany, Orb Diagnostics, Modderfontein, South Africa).

\section{Cytokines}

Interleukin-8, interleukin-1 $\beta$, interleukin-6, interleukin-10, tumour necrosis factor- $\alpha$ and interleukin-12p70 were determined by the Human Inflammation Kit, BD ${ }^{\text {TM }}$ Cytometric Bead Array (CBA) (The Scientific group, Midrand, South Africa). Interleukin-2, interleukin-4, interleukin-5, interleukin-10, tumour necrosis factor- $\alpha$ and interferon- $\gamma$ were determined by the $\mathrm{BD}^{\mathrm{TM}}$ Cytometric Human $\mathrm{T}$-helper cell type-1/T-helper cell type-2 Cytokine Kit (The Scientific group, Midrand, South Africa). With the T-helper cell type-1/T-helper cell type-2 CBA cytokine kit the interferon- $\gamma$ standards were lost and the measurement of interferon- $\gamma$ was done by the human interferon- $\gamma$ ELISA Kit, BD OptEIA ${ }^{\mathrm{TM}}$ test (The Scientific Group, Midrand, South Africa). Transforming growth factor- $\beta 1$ and granulocyte macrophagecolony stimulating factor were determined by their respective ELISAs (DRG Diagnostics, Germany, Orb Diagnostics, Modderfontein, South Africa).

\section{Immunolabelling of the H-subunit and L-subunit of ferritin}

Fixation of bone marrow tissue was performed as described elsewhere [20]. The blocks of bone marrow tissue were sectioned and the sections placed on nickel grids. Immunolabelling procedures were performed by placing each section on a drop of the specific solution. In the first step the sections were incubated with an antigen retrieval solution, $8 \% \mathrm{NaJO}_{4}$ in $\mathrm{H}_{2} \mathrm{O}$, for $1 \mathrm{~h}$ at room temperature. The sections were then rinsed 3 times for $5 \mathrm{~min}$ with phosphate buffered saline ( $20 \mathrm{mmol} / \mathrm{l}$ sodium phosphate buffer and $0.15 \mathrm{~mol} / \mathrm{l}$ sodium chloride, $\mathrm{pH}$ 7.4) at room temperature. After the rinsing steps, the sections were blocked, firstly with $0.05 \%$ glycine in $\mathrm{H}_{2} \mathrm{O}$ for 20 min at room temperature, and secondly, with $1 \% \mathrm{BSA}, 5 \% \mathrm{FBS}$, and $0.05 \%$ Tween-20 in phosphate buffered saline for $1 \mathrm{~h}$ at $30^{\circ} \mathrm{C}$. After the blocking procedures the antibodies were introduced to the sections. Firstly, the sections were incubated with the primary monoclonal antibodies 1:10 (final concentration $50 \mu \mathrm{g} / \mathrm{ml}$ ) diluted in $1 \% \mathrm{BSA}, 5 \% \mathrm{FBS}$, and $0.05 \%$ Tween-20, phosphate buffered saline for $4 \mathrm{~h}$ at $30^{\circ} \mathrm{C}$. After binding of the primary antibodies the sections were rinsed 3 times for $5 \mathrm{~min}$ with $1 \% \mathrm{BSA}, 5 \% \mathrm{FBS}$, and $0.05 \%$ Tween-20 in phosphate buffered saline at room temperature. Rinsing was followed by incubation with the secondary antibody 1:50 diluted in $1 \% \mathrm{BSA}, 5 \% \mathrm{FBS}$, and $0.05 \%$ Tween-20, phosphate buffered saline for $1 \mathrm{~h}$ at $30^{\circ} \mathrm{C}$. After the immunolabelling procedures the sections were rinsed 3 times for $5 \mathrm{~min}$ in $1 \% \mathrm{BSA}, 5 \% \mathrm{FBS}$, and $0.05 \%$ Tween-20 in phosphate buffered saline and finally in only phosphate buffered saline at room temperature for $5 \mathrm{~min}$. Before staining, the sections were fixed with 2\% GA in phosphate buffered saline and rinsed 3 times for 5 min with deionised $\mathrm{H}_{2} \mathrm{O}$ at room temperature. To enhance the contrast of the sections, the sections were stained for 10 min with $0.3 \%$ uranyl acetate at room temperature. For the final rinse the sections were dipped 15 times in 3 separate beakers with deionised $\mathrm{H}_{2} \mathrm{O}$.

The sources of the reagents and antibodies were: $\mathrm{NaJO}_{4}$, sodium (meta) periodate, Fluka, Biochemika, Ultra, cat. no. 71859 from SigmaAldrich, Aston Manor, South Africa; glycine, Pharmacia Biotech, cat. no. 17-1323-01 from AEC Amersham (Pty) Ltd, Sandton, South Africa; BSA (Bovine Serum Albumin), Amersham Biosciences, cat. no. RPN 412 V from Separations Scientific, Randburg, South Africa; FBS (Foetal Bovine Serum), filtered and gamma irradiated, cat. no. 306 from Highveld Biologicals (Pty) Ltd, Halfway House, South Africa; Tween20, polyoxyethylenesorbitan monolaurate, Sigma for Molecular Biology, cat. no. P-9416 from Sigma-Aldrich, Aston Manor, South Africa; primary monoclonal antibody specific for the $\mathrm{H}$-subunit of ferritin (RH02) and primary monoclonal antibody specific for the Lsubunit of ferritin (LF03) from Ramco Laboratories, Inc., Stafford, Texas, United States of America; secondary antibody (anti-mouse IgG, whole molecule, gold conjugate, $10 \mathrm{~nm}$ ), cat. no. G-7777 from SigmaAldrich, Aston Manor, South Africa; uranyl acetate, SPI Supplies, cat. no. 2624 from Rick Loveland \& Associates, Halfway House, South Africa.

The sections were viewed with a Philips 301 transmission electron microscope (FEI, Eindhoven, The Netherlands). With omission of the primary antibodies no non-specific binding for the secondary antibody was seen to either the resin or the tissue. With or without antigen retrieval the amount of non-specific binding of the primary antibodies to the resin was negligible.

\section{Quantification of immunolabelling}

For quantification of the immunolabelling of the H-subunit and Lsubunit of ferritin, the $10 \mathrm{~nm}$ gold particles were counted. The biggest area possible, consisting of only the cytosol of the cell, was demarcated. The number of gold particles in this area was counted and expressed as count $/ \mu^{2}$. ImageTool (UTHSCSA Image Tool for Windows, Version 3, University of Texas, Health Science Centre, San Antonio, Texas, USA) was the software used to measure the area and facilitate the counting process. For each section the number of gold particles was counted in three macrophages, not in close proximity, but on the same section. The mean was calculated and used in the statistical analysis of the data. The gold particles for three representative erythroblasts, three representative reticulocytes and three representative red blood cells were also counted for each patient. These cells were not easily distinguishable in all samples. Cells were all grouped together as cells of the erythron since no difference was shown for the expression of either the H-subunit or for the L-subunit of ferritin between these subsets of cells of the erythron. The mean for this population of cells was used as the count for the cells of the erythron and used in the statistical analysis of the data.

\section{Statistical analysis}

For the H-subunit and L-subunit variables the Welch t-test was used as variances were large and different. Furthermore, since the groups were also relatively small, use was also made of the ranksum (MannWhitney) test. When these results were interpreted, preference was given to the p-value of the ranksum test when the Welch t-test was not significant. For the cytokines, which had skewed distributions, a similar 
Table 1

Cytokine levels for patients with elevated neopterin and patients with normal neopterin.

\begin{tabular}{|c|c|c|c|}
\hline & $\begin{array}{l}\text { Elevated neopterin } \\
(\mathrm{n}=31) \\
\text { Geometric mean; } \\
95 \% \text { confidence interval }\end{array}$ & $\begin{array}{l}\text { Normal neopterin } \\
(\mathrm{n}=13) \\
\text { Geometric mean; } \\
95 \% \text { confidence interval }\end{array}$ & p-value \\
\hline $\begin{array}{l}\text { INF- } \gamma \\
\quad(\mathrm{pg} / \mathrm{ml})\end{array}$ & $\begin{array}{l}1.17 ; \\
0.48-2.84\end{array}$ & $\begin{array}{l}0.25 \\
0.08-0.71\end{array}$ & 0.023 \\
\hline $\begin{array}{l}\text { TNF- } \alpha \\
\quad(\mathrm{pg} / \mathrm{ml})\end{array}$ & $\begin{array}{l}3.12 ; \\
2.54-3.82\end{array}$ & $\begin{array}{l}2.51 ; \\
1.96-3.21\end{array}$ & 0.16 \\
\hline $\begin{array}{l}\mathrm{Il}-1 \beta \\
\quad(\mathrm{pg} / \mathrm{ml})\end{array}$ & $\begin{array}{l}1.20 \\
0.64-2.24\end{array}$ & $\begin{array}{l}0.81 ; \\
0.33-1.98\end{array}$ & 0.45 \\
\hline $\begin{array}{l}\text { Il-6 } \\
\quad(\mathrm{pg} / \mathrm{ml})\end{array}$ & $\begin{array}{l}\text { 43.87; } \\
\text { 20.84-92.34 }\end{array}$ & $\begin{array}{l}4.17 ; \\
1.47-11.80\end{array}$ & 0.0005 \\
\hline $\begin{array}{l}\text { Il-12 } \\
\quad(\mathrm{pg} / \mathrm{ml})\end{array}$ & $\begin{array}{l}2.47 ; \\
1.61-3.80\end{array}$ & $\begin{array}{l}3.45 ; \\
1.73-6.88\end{array}$ & 0.39 \\
\hline $\begin{array}{l}\mathrm{Il}-2 \\
\quad(\mathrm{pg} / \mathrm{ml})\end{array}$ & $\begin{array}{l}6.89 \\
4.52-10.50\end{array}$ & $\begin{array}{l}5.14 ; \\
2.16-12.23\end{array}$ & 0.52 \\
\hline $\begin{array}{l}\mathrm{Il}-8 \\
\quad(\mathrm{pg} / \mathrm{ml})\end{array}$ & $\begin{array}{l}\text { 69.12; } \\
41.33-115.61\end{array}$ & $\begin{array}{l}\text { 11.76; } \\
6.29-21.96\end{array}$ & 0.0001 \\
\hline $\begin{array}{l}\text { GM-CSF } \\
(\mathrm{pg} / \mathrm{ml})\end{array}$ & $\begin{array}{l}2.54 \\
1.37-4.70\end{array}$ & $\begin{array}{l}1.81 ; \\
0.58-5.62\end{array}$ & 0.58 \\
\hline $\begin{array}{l}\mathrm{Il}-4 \\
\quad(\mathrm{pg} / \mathrm{ml})\end{array}$ & $\begin{array}{l}1.81 ; \\
1.29-2.53\end{array}$ & $\begin{array}{l}1.23 ; \\
0.65-2.36\end{array}$ & 0.27 \\
\hline $\begin{array}{l}\mathrm{Il}-5 \\
\quad(\mathrm{pg} / \mathrm{ml})\end{array}$ & $\begin{array}{l}2.92 ; \\
2.21-3.86\end{array}$ & $\begin{array}{l}1.21 ; \\
0.57-2.56\end{array}$ & 0.03 \\
\hline $\begin{array}{l}\text { TGF- } \beta \\
\quad(\mathrm{ng} / \mathrm{ml})\end{array}$ & $\begin{array}{l}8.79 ; \\
7.21-10.71\end{array}$ & $\begin{array}{l}12.51 ; \\
8.31-18.83\end{array}$ & 0.11 \\
\hline $\begin{array}{l}\mathrm{Il}-10 \\
\quad(\mathrm{pg} / \mathrm{ml})\end{array}$ & $\begin{array}{l}9.40 ; \\
6.19-14.26\end{array}$ & $\begin{array}{l}3.24 \\
2.45-4.29\end{array}$ & 0.0001 \\
\hline
\end{tabular}

analysis was done, but for the logarithmic transformed data. For summary statistics of the cytokines the geometric means and their $95 \%$ confidence intervals were reported. Testing was done at the 0.05 level of significance.

\section{Results}

The patients were subdivided according to the immunological indicator neopterin into a group with normal $(<3.4 \mathrm{ng} / \mathrm{ml})$ and a group with elevated $(\geq 3.4 \mathrm{ng} / \mathrm{ml})$ neopterin. This resulted in a group of 13 patients with normal neopterin $(2.2 \pm 0.47 \mathrm{ng} / \mathrm{ml})$ and a group of 31 patients with elevated neopterin $(27.9 \pm 23.5 \mathrm{ng} / \mathrm{ml})$. In order to validate the subdivision based on neopterin the cytokine profiles of these patients were determined. The comparison of the cytokine levels between the two groups is demonstrated in Table 1.

Subsequently, the expression of the subunits of ferritin was compared between the normal and elevated neopterin groups. The results are demonstrated in Table 2. In Fig. 1 an example of the cells used for quantification of immunolabelling can be seen. The expression of the $\mathrm{H}$-subunit of ferritin in the bone marrow macrophage of patients with elevated neopterin was significantly higher than that of patients with normal neopterin. In addition, the H-subunit/L-subunit ratio in the macrophage was significantly higher in the group with elevated neopterin than in the group with normal neopterin. No significant difference was found for the L-subunit of ferritin in the bone marrow macrophage between the groups. No significant differences were found in the expression of the H-subunit and L-subunit in the cells of the erythron.

\section{Discussion}

The functional characteristics of intracellular ferritin depend on the subunits that constitute the ferritin molecule - in other words the type of isoferritin. As isoferritins have different functional characteristics, quantitative information on the expression of the subunits in different types of cells, and in different conditions, is necessary to better understand the intracellular role of ferritin.

In the bone marrow iron is metabolised in different ways by cells of the erythron on the one hand, and the bone marrow macrophage on the other. Iron is shuttled between the macrophage and cells of the erythron to support erythropoiesis, but during conditions of chronic immune stimulation, iron is retained by the macrophage resulting in an increase in storage iron and hypoferraemia (the so-called iron transfer block) accompanied by the anaemia of chronic disease [21].

In order to understand the role of ferritin and more specifically the subunits of ferritin in the handling of iron by the macrophage and cells of the erythron in the bone marrow it is necessary to have quantitative information on the expression of the two subunits of ferritin, the $\mathrm{H}$ subunit and L-subunit, at the cellular level. Several in vitro studies point towards the differential expression of the $\mathrm{H}$-subunit and Lsubunit of ferritin in a number of tissues in conditions marked by the excessive production of toxic oxygen radicals, and by infectious or inflammatory processes [10-18]. However, despite a few in vivo studies [22-24], no quantitative information is available on the differential expression of the subunits in the macrophage and cells of the erythron in the bone marrow in patients with confirmed proinflammatory states.

The present study focused on the intracellular expression of the $\mathrm{H}$ subunit and L-subunit of ferritin at the single cell level in the bone marrow macrophage and in cells of the erythron in patients with cellular immune activation. Neopterin, a macrophage product upon stimulation by interferon- $\gamma$ (INF- $\gamma$ ), was determined in order to assess the involvement of cell-mediated (pro-inflammatory) immunity. Plasma neopterin levels are often employed to monitor the magnitude of cellular immune activation/involvement during an immune response [25]. Based on neopterin values the patients were subdivided into a group with pronounced cellular immune activation and a group with normal cellular immune activity. In order to validate this neopterin-based subdivision, the cytokine profiles were determined.

When the validity of the subdivision according to neopterin levels was tested against the cytokine results the high neopterin group demonstrated a predominantly pro-inflammatory profile. The proinflammatory cytokines INF- $\gamma$, interleukin-6 (Il-6) and Il-8 were significantly higher in the group with elevated neopterin levels than in the group with normal neopterin levels. It is known that the activating signals for the classically activated macrophage (type- 1 activated macrophage/pro-inflammatory macrophage) include INF- $\gamma$, tumour

Table 2

Gold particle counts for the H-subunit and L-subunit of ferritin for patients with elevated neopterin and patients with normal neopterin.

\begin{tabular}{|c|c|c|c|}
\hline & $\begin{array}{l}\text { Elevated neopterin } \\
(\mathrm{n}=31)\end{array}$ & $\begin{array}{l}\text { Normal neopterin } \\
(\mathrm{n}=13)\end{array}$ & p-value \\
\hline H-subunit macrophage & $94.7 \pm 37.3$ counts $/ \mu \mathrm{m}^{2}$ & $72.4 \pm 34.0$ counts $/ \mu \mathrm{m}^{2}$ & 0.037 \\
\hline L-subunit macrophage & $108.1 \pm 34.3$ counts $/ \mu \mathrm{m}^{2}$ & $126.8 \pm 47.5$ counts $/ \mu \mathrm{m}^{2}$ & 0.147 \\
\hline H-subunit/L-subunit ratio macrophage & $0.97 \pm 0.49$ & $0.66 \pm 0.43$ & 0.023 \\
\hline H-subunit cells of the erythron & $141.4 \pm 54.6$ counts $/ \mu \mathrm{m}^{2}$ & $127.8 \pm 53.3$ counts $/ \mu \mathrm{m}^{2}$ & 0.322 \\
\hline L-subunit cells of the erythron & $200.7 \pm 54.9$ counts $/ \mu \mathrm{m}^{2}$ & $245.7 \pm 85.7$ counts $/ \mu \mathrm{m}^{2}$ & 0.115 \\
\hline H-subunit/L-subunit ratio cells of the erythron & $0.77 \pm 0.42$ & $0.57 \pm 0.31$ & 0.062 \\
\hline
\end{tabular}



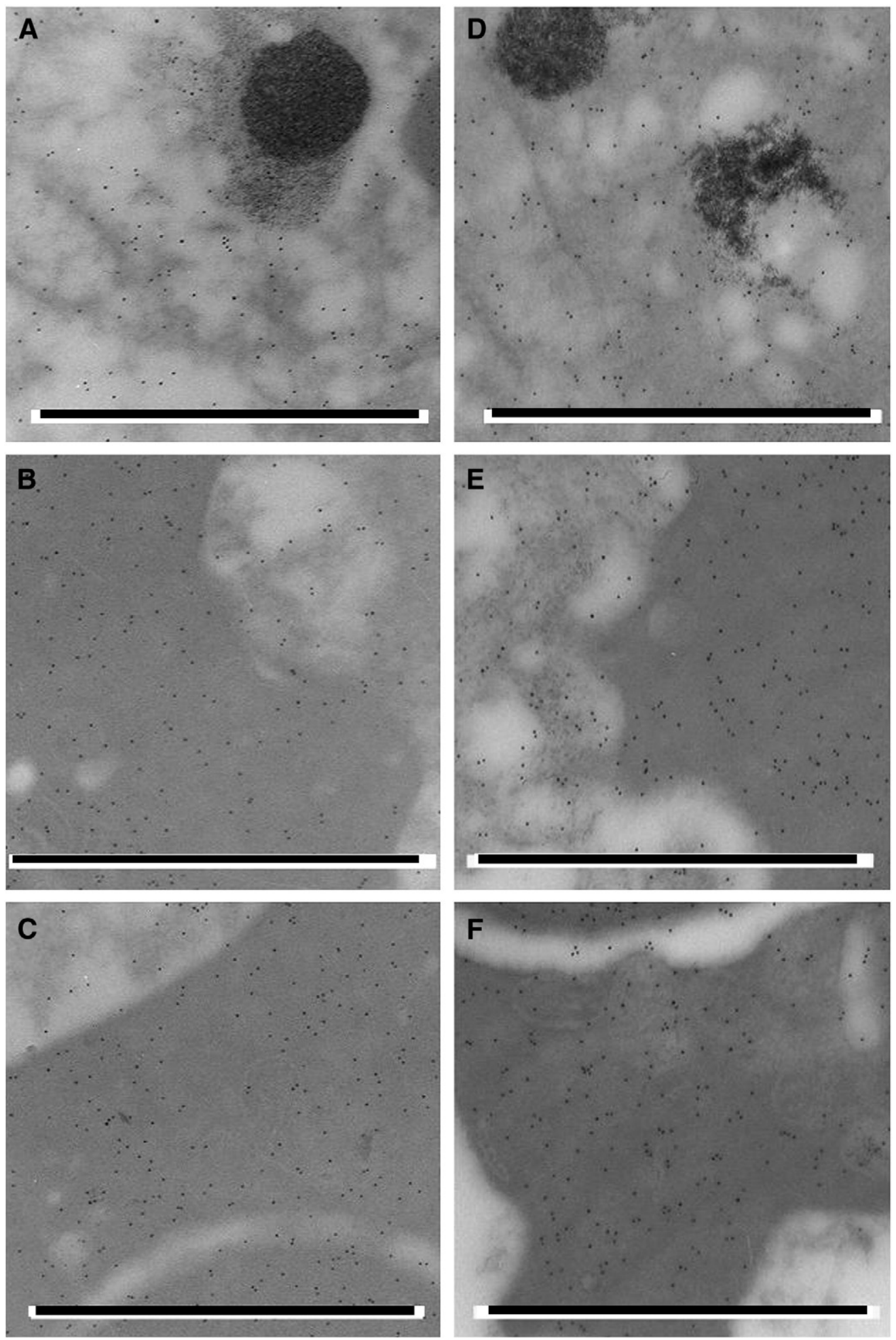

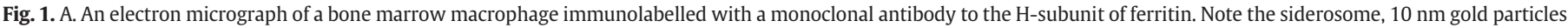

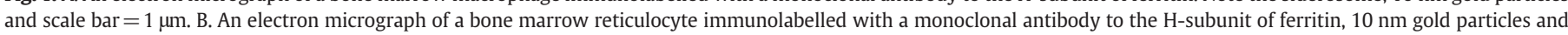

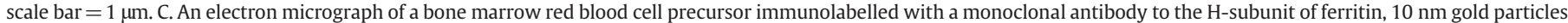

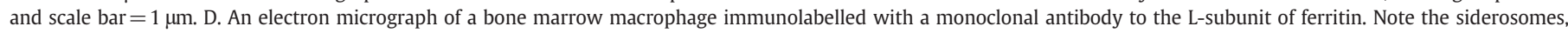

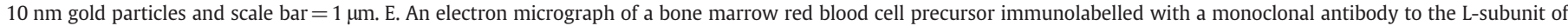

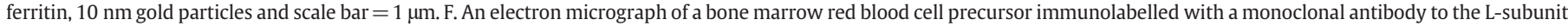
of ferritin, $10 \mathrm{~nm}$ gold particles and scale bar $=1 \mu \mathrm{m}$.

necrosis factor- $\alpha$ (TNF- $\alpha$ ) and Il-2, and the major secretory products are TNF- $\alpha$, Il-12, Il-1 $\beta$, Il-6 and Il-8 [26-28]. However, IFN- $\gamma$ is the cytokine of major importance in the classical activation of the macrophage. IFN- $\gamma$ augments the activation of macrophages in response to bacterial products, such as lipopolysaccharide (LPS), pro-inflammatory cytokines including TNF- $\alpha$, Il-1 $\beta$ and Il-12, or activated T-lymphocytes through 
the CD40 ligand [29]. When the macrophage is activated by one of these stimuli without IFN- $\gamma$ being present, the absolute amount of cytokines and toxic nitrogen radicals released is many-fold lower than for macrophages that have been exposed to activating stimuli in the presence of IFN- $\gamma$ [29]. Il- 6 tends to be more of a secondary mediator, fundamental for the acute phase response in the liver and has a regulatory function in the immune response [28]. The chemokine, Il-8, is responsible for the recruitment of leukocytes such as the neutrophil to the inflammatory site [30]. No significant differences were shown between the two groups for Il- $1 \beta$ and TNF- $\alpha$ or for Il- 2 and Il- 12 . The latter may have been as a result of the many HIV-positive patients included in the elevated neopterin group. With human immunodeficiency virus infection the production of both Il-2 and Il-12 are reduced [31,32]. The T-helper cell type-2 cytokines (anti-inflammatory cytokines) were, but for Il-5 and Il-10, not different between the patients with elevated neopterin and the group with normal neopterin. The production of Il-10 with cellular immune activation is consistent with its central role in the regulation and containment of inflammatory responses by the modulation of both pro- and anti-inflammatory activities [33]. Furthermore, Il-10 can up-regulate the expression of ferritin $[34,35]$. For transforming growth factor- $\beta$ (TGF- $\beta$ ), no significant difference was shown for the patients with elevated neopterin compared to the patients with normal neopterin.

Subsequently, the expression of the ferritin subunits was compared between the group with elevated and the group with normal neopterin. In the patients with elevated neopterin the expression of the $\mathrm{H}$-subunit of ferritin in the bone marrow macrophage was significantly higher, $\mathrm{p}$-value $=0.037$, than in the patients with normal neopterin. No difference was shown for the expression of the Lsubunit of ferritin in the bone marrow macrophage between the group of patients with elevated and the patients with normal neopterin. The H-subunit/L-subunit ratio in the macrophage was significantly higher ( $p$-value $=0.023$ ) in the group of patients with elevated neopterin than in the patients with normal neopterin. In fact, the patients with elevated neopterin had about one L-subunit for every $\mathrm{H}$-subunit, while the patients with normal neopterin had one and a half times as many L-subunits for every H-subunit.

In the cells of the erythron, the expression of the H-subunit of ferritin was not significantly different between the patients with elevated and the patients with normal neopterin. Neither was a significant difference found between the two groups for the expression of the L-subunit of ferritin in the cells of the erythron. However, the H-subunit/L-subunit ratio in the cells of the erythron was marginally higher, $p$-value $=0.062$, in the patients with elevated neopterin than in the group of patients with normal neopterin.

Although, a significant increase was shown in the macrophage $\mathrm{H}-$ subunits, the expression was probably even higher than observed since two processes induced by cytokines can reduce the levels of the $\mathrm{H}$-subunit of ferritin. Firstly, pro-inflammatory cytokines have been shown to increase the secretion of ferritin from cells into extracellular fluids [36]. The second process, that could have brought about a lower observed increase in the H-subunit of ferritin, also induced by proinflammatory cytokines, is the degradation of ferritin during haemosiderin formation. As discussed elsewhere [37], H-subunit rich ferritins, in preference to L-subunit rich ferritins, are directed into lysosomes during the formation of haemosiderin. Of interest is the fact that activation of macrophages by pro-inflammatory cytokines such as TNF- $\alpha$ can result in the slower release of iron, thus supporting the proposed role of cytokines in ferritin-mediated iron sequestration by macrophages $[38,39]$, and possibly an indirect role for $\mathrm{H}$-subunits in the iron transfer block of inflammation.

The results of this study thus showed the expression of the $\mathrm{H}$ subunit of ferritin in the bone marrow macrophage to be higher and the expression of the L-subunit of ferritin in the macrophage to be unaffected in patients with increased cellular immune activity. It is feasible to accept that the higher $\mathrm{H}$-subunit count reflected isoferritins containing a higher quantity of $\mathrm{H}$-subunits. In contrast, the expression of both the H-subunit and the L-subunit in the cells of the erythron in the bone marrow was unaffected in the patients with a proinflammatory immune status.

The findings of this quantitative, in vivo study on bone marrow macrophages are in line with in vitro experiments with various cell types that showed an increase in $\mathrm{H}$-subunit expression relative to L-subunit expression upon cytokine activation [15,36,40-43].

In view of the presumed functional characteristics of the $\mathrm{H}$-subunit of ferritin [37], the increase in its expression seen in this study is consistent with the role ascribed to ferritin in the sequestration and with-holding of iron. This accumulation of iron in the macrophages with consequential haemosiderosis of the macrophage and reduction in serum iron [21], will result in less iron reaching the cells of the erythron for the production of haemoglobin. In addition, although the cells of the erythron's H-subunit of ferritin were not up-regulated in the present study, the H-subunit/L-subunit ratio in the cells of the erythron was higher in the patients with elevated neopterin than in those with normal neopterin. In an in vitro study it was shown that an increase in $\mathrm{H}$-subunit rich ferritins in erythroid cells could result in chelation of the labile iron pool [44]. This increase in erythron $\mathrm{H}-$ subunits relative to L-subunits could potentially contribute to the development of the anaemia of chronic disease in which macrophage iron-withholding plays an important role.

\section{References}

[1] N.D. Chasteen, Ferritin. Uptake, storage, and release of iron, Met. Ions Biol. Syst. 35 (1998) 479-514.

[2] P. Arosio, S. Levi, P. Santambrogio, A. Cozzi, A. Luzzago, G. Cesareni, A. Albertini, Structural and functional studies of human ferritin $\mathrm{H}$ and $\mathrm{L}$ chains, Curr. Stud. Hematol. Blood Transfus. 58 (1991) 127-131.

[3] E. Chiancone, S. Stefanini, Heterogeneity of ferritin. I. Structural and functional aspects, in: A. Albertini, P. Arosio, E. Chiancone, J. Drysdale (Eds.), Ferritins and Isoferritins as Biochemical Markers, Elsevier Science Publishers, Amsterdam, 1984, pp. 23-32.

[4] E.G. Meyron-Holtz, E. Fibach, D. Gelvan, A.M. Konijn, Binding and uptake of exogenous isoferritins by cultured human erythroid precursor cells, Br. J. Haematol. 86 (1994) 635-641.

[5] H.E. Broxmeyer, P. Gentile, I. Listowsky, F. Cavanna, H.J. Feickert, M.H. Dorner, G. Ruggeri, M. Cazzola, S. Cooper, Acidic isoferritins in the regulation of hematopoiesis in vitro and in vivo, in: A. Albertini, P. Arosio, E. Chiancone, J. Drysdale (Eds.), Ferritins and Isoferritins as Biochemical Markers, Elsevier Science Publishers, Amsterdam, 1984, pp. 97-111.

[6] S.V. Torti, F.M. Torti, Iron and ferritin in inflammation and cancer, Adv. Inorg. Biochem. 10 (1994) 119-137.

[7] J. Rogers, L. Lacroix, G. Durmowitz, K. Kasschau, J. Andriotakis, K.R. Bridges, The role of cytokines in the regulation of ferritin expression, Adv. Exp. Med. Biol. 356 (1994) 127-132.

[8] Y. Tsuji, H. Ayaki, S.P. Whitman, C.S. Morrow, S.V. Torti, F.M. Torti, Coordinate transcriptional and translational regulation of ferritin in response to oxidative stress, Mol. Cell. Biol. 20 (16) (2000) 5818-5827.

[9] O. Kakhlon, Y. Gruenbaum, Z.I. Cabantchik, Repression of ferritin expression increase the labile iron pool, oxidative stress, and short-term growth of human erythroleukemia cells, Blood 97 (9) (2001) 2853-2871.

[10] M.A. Bevilacqua, F. Costanzo, L. Buonaguro, F. Cimino, Ferritin H and L mRNAs in human neoplastic tissues, Ital. J. Biochem. 37 (1) (1988) 1-7.

[11] J.R. Connor, B.S. Snyder, P. Arosio, D.A. Loeffler, P. LeWitt, A quantitative analysis of isoferritins in select regions of aged, Parkinsonian, and Alzheimer's diseased brains, J. Neurochem. 65 (1995) 717-724.

[12] N.A. Higgy, A.M. Salicioni, I.H. Russo, P.L. Zhang, J. Russo, Differential expression of human ferritin $\mathrm{H}$ chain gene in immortal human breast epithelial MCF-10F cells, Mol. Carcinogenesis 20 (4) (1997) 332-339.

[13] B.M. Jones, M. Worwood, A. Jacobs, Serum ferritin in patients with cancer: determination with antibodies to HeLa cell and spleen ferritin, Clin. Chim. Acta 106 (1980) 203-214.

[14] F. Lin, A.W. Girotti, Elevated ferritin production, iron containment, and oxidant resistance in hemin-treated leukaemia cells, Arch. Biochem. Biophys. 346 (1) (1997) $131-141$.

[15] L.L. Miller, S.C. Miller, S.V. Torti, Y. Tsuji, F.M. Torti, Iron-independent induction of ferritin H chain by tumor necrosis factor, Proc. Natl. Acad. Sci. USA 88 (11) (1991) 4946-4950.

[16] P.K. Tripathi, S.K. Chatterjee, Elevated expression of ferritin H-chain mRNA in metastatic ovarian tumor, Cancer Invest. 14 (6) (1996) 518-526.

[17] M. Vernet, J.C. Renversez, Y. Lasne, M.C. Revenant, C. Charlier-de-Bressing, C. Guillemin, M. Pressac, J.C. Rymer, Comparison of six serum ferritin immunoassays and isoferritin spectrotypes in malignancies, Ann. Biol. Clin. 53 (1995) 419-427. 
[18] D. Whittaker, J.D. Torrance, M.C. Kew, Isolation of ferritin from human hepatocellular carcinoma, Scand. J. Haematol. 33 (5) (1984) 432-439.

[19] E.C. Theil, The ferritin family of iron storage proteins, Adv. Enzymol. Relat. Areas Mol. Biol. 63 (1990) 421-449.

[20] A.M. Koorts, P.F. Levay, P.J. Becker, M. Viljoen, Pro- and anti-inflammatory cytokines during immune stimulation: modulation of iron status and red blood cell profile, Mediat. Inflamm. (2011), doi:10.1155/2011/716301.

[21] X. Alvarez-Hernández, J. Licéaga, I.C. McKay, J.H. Brock, Induction of hypoferremia and modulation of macrophage iron metabolism by tumor necrosis factor, Lab. Invest. 61 (3) (1989) 319-322.

[22] E. Miyazaki, J. Kato, M. Kobune, K. Okumura, K. Sasaki, N. Shintani, P. Arosio, Y. Niitsu, Denatured H-ferritin subunit is a major constituent of haemosiderin in the liver of patients with iron overload, Gut 50 (3) (2002) 413-419.

[23] G. Ruggeri, P. Santambrogio, F. Bonfiglio, S. Levi, G. Bugari, R. Verardi, M. Cazzola, R. Invernizzi, Antibodies for denatured human H-ferritin stain only reticuloendothelial cells within the bone marrow, Br. J. Haematol. 81 (1992) 118-124.

[24] R. Invernezzi, M. Cazzola, P. De Fazio, V. Rosti, G. Ruggeri, P. Arosio, Immunocytochemical detection of ferritin in human bone marrow and peripheral blood cells using monoclonal antibodies specific for the $\mathrm{H}$ and $\mathrm{L}$ subunit, $\mathrm{Br}$. J. Haematol. 76 (30) (1990) 427-432.

[25] C. Murr, B. Widner, B. Wirleitner, D. Fuchs, Neopterin as a marker for immune system activation, Curr. Drug Metabol. 3 (2002) 175-187.

[26] D.M. Mosser, The many faces of macrophage activation, J. Leukoc. Biol. 73 (2003) 209-212.

[27] Y. Ohmori, T.A. Hamilton, Regulation of macrophage gene expression by T-cell derived lymphokines, Pharmacol. Therapy 63 (1994) 235-264.

[28] A. Montavani, A. Sica, M. Locati, New vistas on macrophage differentiation and activation, Eur. J. Immunol. 37 (2007) 14-16.

[29] J.S. Duffield, The inflammatory macrophage: a story of Jekyll and Hyde, Clin. Sci. 104 (2003) 27-38.

[30] S. Keshav, L.-P. Chung, S. Gordon, Macrophage products in inflammation, Diagn. Microbiol. Infect. Dis. 13 (1990) 439-447.

[31] M. Kryworuchko, J. Thèze, Interleukin-2: from T cell growth and homeostasis to immune reconstitution of HIV patients, Vitam. Horm. 74 (2006) 531-547.

[32] G. Nunnari, L. Nigro, D. Palermo, D. Leto, R.J. Pomerantz, B. Cacopardo, Reduction of serum melatonin levels in HIV-1-infected individuals' parallel disease progression: correlation with serum interleukin-12 levels, Infection 31 (6) (2003) 379-382.

[33] F. Bazzoni, N. Tamassia, M. Rossato, M.A. Cassatella, Understanding the molecular mechanisms of the multifaceted IL-10-mediated anti-inflammatory response: lessons from neutrophils, Eur. J. Immunol. 40 (9) (2010) 2360-2368.

[34] G. Weiss, L.T. Goodnough, Anemia of chronic disease, New Engl. J. Med. 352 (10) (2005) 1011-1023.

[35] S. Ludwiczek, E. Aigner, I. Theurl, G. Weiss, Cytokine-mediated regulation of iron transport in human monocytic cells, Blood 101 (10) (2003) 4148-4154.

[36] F.M. Torti, S.V. Torti, Regulation of ferritin genes and protein, Blood 99 (10) (2002) 3505-3516.

[37] A.M. Koorts, M. Viljoen, Ferritin and ferritin isoforms I: structure-function relationships, synthesis, degradation and secretion, Arch. Physiol. Biochem. 113 (1) (2007) 30-54.

[38] X. Alvarez-Hernández, M.V. Felstein, J.H. Brock, The relationship between iron release, ferritin synthesis and intracellular iron distribution in mouse peritoneal macrophages. Evidence for a reduced level of metabolically available iron in elicited macrophages, Biochim. Biophys. Acta 886 (1986) 214-222.

[39] A. Savarino, G.P. Pescarmona, J.R. Boelaert, Iron metabolism and HIV infection: reciprocal interactions with potentially harmful consequences, Cell Biochem. Funct. 17 (1999) 279-287.

[40] J.T. Rogers, K.R. Bridges, G.P. Durmowicz, J. Glass, P.E. Auron, H.N. Munro, Translational control during the acute phase response; ferritin synthesis in response to interleukin-1, J. Biol. Chem. 265 (24) (1990) 14572-14578.

[41] J.T. Rogers, Ferritin translation by interleukin-1 and interleukin-6: the role of sequences upstream of the start codons of the heavy and light subunit genes, Blood 87 (6) (1996) 2525-2537.

[42] J.-H.S. Pang, M.-J. Jiang, Y.-L. Chen, F.-W. Wang, D.L. Wang, S.-H. Chu, L.Y. Chau, Increased ferritin gene expression in atherosclerotic lesions, J. Clin. Invest. 97 (10) (1996) 2204-2212.

[43] S.W. Stites, M.W. Plautz, K. Bailey, A.R. O'Brien-Ladner, L.J. Wesselius, Increased concentrations of iron and isoferritins in the lower respiratory tract of patients with stable cystic fibrosis, Am. J. Resp. Crit. Care Med. 160 (3) (1999) 796-801.

[44] V. Picard, F. Renaudie, C. Porcher, M.W. Hentze, B. Grandchamp, C. Beaumont, Overexpression of the ferritin $\mathrm{H}$ subunit in cultured erythroid cells changes the intracellular iron distribution, Blood 87 (5) (1996) 2057-2064. 